\title{
Kompetensi Juru Dakwah dalam Pandangan Jama'ah Tabligh
}

\author{
M. Azizzullah Ilyas \\ Sekolah Tinggi Agama Islam Negeri Curup \\ alcurufi@gmail.com
}

\begin{abstract}
The movement of dawah Tablighi Jamaat has been going on almost all regions of Indonesia even worldwide, this can be seen from the scope of the movement of Tablighi Jamaat cross-country, but in practice there is often a friction between the da'i of Tablighi Jamaat and society that can be observed from some village or mosques that reject the presence of Tablighi Jamaat, it is necessary to know how the actual concept of dawab competence according to Tablighi Jamaat and how the effort Tablighi Jamaat do in foster da'i that will be work In the community. This study uses an analytical descriptive approach and combines library studies, participant observation and interviews. The study found that Tablighi Jamaat has several references and competencies that must be possessed by da'i, there are thirteen major competencies that are termed with the 'character of dai'. This competence is support the development of dawah, but in the field, found that many members of Tablighi Jamaat not understand the intent of these 13 characters and some of them have not applied this competence in dawah, in fact members of Tablighi Jamaat not be required to be good first before joining in dawah aktivity, this opinion based on to the hadith of the prophet "conver from me, even if it is one verse".
\end{abstract}

Keywords : tablighi jamaat, competence, da'i

Abstrak
Gerakan dakwah jama'ah tabligh telah berlangsung hampir diseluruh
wilayah Indonesia bahkan mendunia, hal ini dapat dilihat dari cakupan
gerakan dakwah jama'ah tabligh yang lintas negara, namun dalam
prakteknya kerap kali terjadi gesekan antara para pendakwah jama'ah
tabligh dan masyarakat yang dapat diamati dari beberapa masjid
perkampungan ataupun desa yang menolak kehadiran dakwah jama'ah
tabligh, maka perlu diketahui bagaimana sesungguhnya konsep kompetensi
juru dakwah menurut jama'ah tabligh dan bagaimana upaya jama'ah
tabligh lakukan dalam membina da'i-da'i yang akan diterjunkan untuk
berdakwah dimasyarakat. Penelitian ini menggunakan pendekatan


deskriptif analitis dan memadukan antara studi kepustakaan, observasi partisipasi dan wawancara. Penelitian menemukan bahwa jama'ah tabigh memiliki beberapa acuan dan kompetensi yang harus dimiliki oleh seorang juru dakwah, terdapat tiga belas kompetensi utama yang di istilabkan dengan sifat da'i. Kompetensi tersebut mendukung perkembangan dakwah, banya saja dilapangan ditemukan babwa masib banyak juru da'wah Jamaah Tabligh belum memahami maksud dari 13 sifat tersebut dan beberapa dari mereka belum mengaplikasikean tiga belas sifat tersebut dalam berdakwah, dalam dakwah jama'ah tabligh seorang da'i tidak dituntut harus menguasai kompetensi tersebut sebelum berdakwah mereka berpegang pada hadits nabi yang berbunyi sampaikan olebmu apa yang datang dariku meskipun satu ayat.

Kata Kunci : jama'ah tabligh, kompetensi, da'i

\section{Pendahuluan}

Fenomena gerakan dakwah yang terjadi di Indonesia terus mengalami pasang surut, kemunculan komunitas dan kelompok dakwah baru dengan karakteristik yang berbeda-beda menjadi menarik untuk diamati. Pendekatan, metode dan tema dakwah yang digunakan oleh kelompok dan komunitas dakwah baru merangsang komunitas dan organisasi masyarakat keagamaan yang telah ada untuk melihat kembali dan turut mengembangkan pendekatan dan strategi dalam berdakwah.

Dalam gerakan dakwah terdapat tiga metode yang kerap digunakan, dakwah bil khitobah yang lebih menitik beratkan komunikasi verbal dan non verbal, dakwah bil kitabah dimana proses dakwah menggunakan sarana tulisan, dan dakwah bil hal yang merupakan proses dakwah melalui tindakan langsung sesuai dengan kapasitas, kemampuan dan profesi masing-masing. ${ }^{1}$

Sebagai sebuah gerakan sosial, kegiatan dakwah memerlukan kemampuan berkomunikasi yang mampu menyampaikan pesan yang ingin disampaikan. Umat Islam selain dituntut untuk merealisasikan ajaran Islam dalam kehidupan secara individu juga dibebani tanggung jawab sosial untuk berkontribusi dalam merealisasikan ajaran Islam secara kolektif.

Dalam kegiatannya juru dakwah hendaknya memahami bahwa dakwah yang baik adalah dakwah yang sesuai dengan metode dakwah yang

\footnotetext{
${ }^{1}$ Imam Moedjiono. Metode Dakwah Praktis (Yogyakarta: As-Salam Press. 2004),
} 
terdapat dalam al-Qur'an, dan dilakukan dengan senantiasa menghormati ka'idah berfikir dan berkeyakinan. Dan seorang juru dakwah memiliki kewajiban untuk berdakwah yang harus ditunaikannya dan kemerdekaan berkeyakinan penerima dakwah. Kekuatan dakwah juru dakwah terletak pada kekuatan hujahnya yang dapat diterima oleh akal sehat, kemampuan berkomunikasi yang dapat menyentuh dan menggerakkan jiwa dan rasa. Kesemuannya itu bergantung kepada bagaimana kesiapan metal seorang juru dakwah, wawasan keilmuan dan kaifiyat dan adab dakwah yang digunakan. ${ }^{2}$

Da'i adalah seseorang yang melakukan ajakan atau orang yang menyampaikan ajaran (muballigh). Subjek dakwah merupakan unsur penting dalam pelaksanaan dakwah karena seorang da'i akan menjadi pemandu titian yang mengemban misi risalah dan diserukan kepada objek dakwah dengan dalil yang dapat dipertanggungjawabkan kebenarannya. Seorang da'i dituntut mampu mengetuk dan menyentuh hati umat yang dihadapinya secara profesional agar misi yang disampaikan dapat diterima oleh umat. ${ }^{3}$

Kata da'i berasal dari bahasa Arab, ibnu manzur menjelaskan bahwa da'i memiliki makna seseorang yang mengajak kepada sesuatu baik sesuatu itu baik atau buruk. ${ }^{4}$ Da'i yang mengajak kepada kebenaran adalah da’i yang mengajak kepada Allah swt dengan bukti dan dalil yang sahih baik yang bersumber dari al-Qur'an dan Hadits ataupun bukti-bukti yang dapat diterima oleh akal dan dengan mengikuti cara-cara yang dicontohkan oleh nabi Muhammad SAW. Maka dapat dipahami bahwa da'i merupakan orang Islam yang mengajak kepada Islam, mengajarkannya dan berusaha untuk menerapkan dan mewujudkannya.

Dalam perkembangan dakwah di Indonesia selain organisasi dan kelompok dakwah yang berafiliasi dengan mazhab tertentu seperti Muhammadiyah, Nahdhatul Ulama yang merupakan produk asli Indonesia muncul banyak kelompok dan gerakan dakwah pasca reformasi seperti

\footnotetext{
${ }^{2}$ Muhammad Natsier. Fikhu Da'wah (Jakarta: Media Da’wah, 2006), 132-133

3 Aris Risduana. "Transformasi Peran da'i dalam Menjawab Peluang dan Tantangan". Jurnal Dakwah, Vol. XV, No.2 (2014), 438

${ }^{4}$ Ibnu Manzur. Lisanul Arab vol. 14.(Beirut: Dar Sadhr), 259
} 
gerakan Salafi, ${ }^{5}$ Hizbut Tahrir, ${ }^{6}$ Ikhwanul Muslimin, Global Ikhwan ${ }^{7}$ yang berasal dari luar Indonesia dan membentuk komunitas dan wilayah dakwah dengan karakteristik dan mazhab tertentu dalam wilayah fiqh dan aqidah menyebabkan adanya semacam dinding yang membatasi wilayah dakwah kelompok tersebut untuk dapat menyentuh seluruh lapisan masyarakat tanpa memandang perbedaan mazhab fiqh.

Jama'ah Tabligh (JT) sebagai kelompok dakwah yang terus berkembang dan berkonsentrasi dalam gerakan dakwah memiliki kekhasan dalam memandang persoalan perbedaan mazhab dalam fiqh. Dalam aktivitas dakwahnya kelompok JT tidak menitik beratkan pada persoalan fiqih bahkan di India negara dimana gerakan ini pertama kali muncul dan berkembang. Para tokoh JT di India dan Pakistan ataupun diberbagai negara yang dikenal dengan istilah masyekh yang mengikuti mazhab fiqh yang berbeda-beda dan dapat beradaptasi dengan mazhab apapun yang diterima oleh kalangan ahlu sunnah wal jama'ah dimana mereka berdakwah.

${ }^{5}$ Aliran salafi lahir pada abad ke IV H, digerakkan oleh pengikut mazhab Hanbali dan digerakkan kembali pada abad ke VII oleh Ibnu Taimiyah. Keyakinan ini selanjutnya dikembangkan oleh Muhammad bin Abdul Wahab pada abad ke XII H dengan bantuan Raja as-sa'ud dan menyiarkan ajarannya dengan kekerasan. Aboebakar Atjeh, Ilmu Ketuhanan. Tintamas: Jakarta, 1966., h85. Penamaan "ulang” nama Salafi dipopulerkan oleh Muhammad Nashiruddin al-Albani (1914-1999) tahun 1960-an di Madinah, melalui jamaahnya yang dikenal dengan Jamaah al-Salafiyah al-Muhtasibah. Ajaran Salafi yang dikembangkan oleh al Albani pada dasarnya sama dengan doktrin yang dikembangkan oleh Muhammad Ibn Abdul Wahhab, yaitu memurnikan kembali ajaran Islam dengan menghilangkan semua yang dianggap bid'ah dan syirik sesuai dengan pemahaman mereka. As'ad Said Ali, Ideologi Gerakan Pasca-Reformasi: Gerakan-gerakan Sosial-Politik Dalam Tinjauan Ideologis, (Jakarta: LP3ES, 2012), 106.

${ }^{6}$ Hizbut Tahrir (HT) berdiri di al-Quds Palestina pada tahun 1953. Pendirinya adalah Syaikh Taqiyuddin al-Nabhani. Secara historis, HT berdiri sebagai respon terhadap keterpurukan umat Islam dalam waktu yang panjang. Karena sejak abad ke-19 M, peradaban Islam berada di titik nadir. Dalam pandangan HT, hanya dengan sistem khilafah inilah hukum-hukum Allah dapat ditegakkan dan syarie at bisa dijalankan secara kaffah. Mohamad Rafiuddin. "Mengenal Hiz̨but Tabrir”, Jurnal Islamuna, Vol. 2, No. 1 (2015), 33 34.

${ }^{7}$ Global Ikhwan Global Ikhwan merupakan gerakan neo-sufi yang muncul di Malaysia dengan kerajaan bisnisnya. Darul Arqam kemudian bertransformasi menjadi Korporasi Rufaqa', pada tahun 1998 kembali merubah nama menjadi Global Ikhwan. Ahmad Fauzi Abdul Hamid." Islamist Civil Society Activism in Malaysia under Abdullah Badawi: the Angkatan Belia Islam Malaysia (ABIM) and the Darul Arqam” (Jurnal Studia Islamika, Vol. 16, No. 3, 2009), 440. gerakan ini berkembang dan diterima di Sumatera Selatan dan Jawa berbentuk komunitas. Di Palembang Global Ikhwan dikukuhkan sebagai bagian dari Kesultanan Palembang Darussalam. 
Hal ini dapat dilihat dalam praktek khuruj, yaitu aktivitas memobilisasi umat agar dapat hadir di masjid untuk melaksanakan ibadah ritual yang dilanjutkan dengan taklim dan diskusi secara halaqah dan berdakwah dengan cara berpindah-pindah dari masjid ke masjid yang dilakukan dalam waktu 3 hari, 40 hari atau 4 bulan dan bagi mereka yang dipandang memiliki pengetahuan agama yang lebih khuruj dalam waktu satu tahun. Perdebatan-perdebatan fiqh menjadi tidak menarik bahkan tidak dibicarakan dalam praktek dakwah mereka, ranah fiqh menjadi persoalan individu dan masing-masing diberikan kebebasan untuk mengikuti salah satu dari empat mazhab utama ahlu sunnah wal jama'ah. Dalam praktek dakwah mereka para tokoh JT menganjurkan untuk tetap berpegang kepada mazhab fiqh mayoritas dinegara mereka.

Meninggalkan perdebatan mazhab dan tidak menyentuh persoalan politik menyebabkan perkembangan gerakan dakwah JT dapat diterima dan berkembang hampir diseluruh negara yang memiliki penduduk muslim baik mayoritas ataupun minoritas. Diantara orientasi utama gerakan JT adalah menyatukan umat. Semangat ini diikuti berbagai doktrin, diantarannya menghindari membicarakan dan mewacanakan politik baik dalam dalam dan luar negeri, menghindari perbedaan dan perdebatan dalam mazhabmazhab baik dalam fiqh ataupun dalam aqidah, selain itu juga dilarang membicarakan aib-aib masyarakat, membicarakan status sosial, kedudukan, keadaan ekonomi masyarakat, serta meminta dana, derma, sumbangan, zakat kepada masyarakat.

Dalam aktivitasnya juru dakwah hendaknya memiliki potensi dan kompetensi yang mumpuni, baik secara lahir maupun batin. Kompetensi dalam oxford dictionary bermakna kemampuan untuk melaksanakan sesuatu dengan dengan baik dan efisien. Kata kompetensi dalam bahasa Arab berpadanan dengan kata kafa'ah dan Kudrah yang dalam mu'jam al-wasit bermakna keahlian dalam melakukan sesuatu dengan baik.

Aktivitas dakwah akan dapat terlaksana bila memenuhi tiga rukun dakwah: juru dakwah (da'i), objek dakwah (mad'u) dan tema atau materi dakwah dan mengingat bahwa dakwah merupakan kerja para nabi, maka juru dakwah hendaknya memiliki beberapa kompetensi diantaranya keimanan, kedekatan kepada Allah swt diiringi keikhlasan dalam berdakwah dan rasa cinta kepada Allah swt, memiliki pengetahuan mengenai ilmu agama dan pengetahuan akan apa yang disampaikan juga pengetahuan 
mengenai bukti serta dalil, memiliki sifat istiqomah dalam berdakwah dan mengamalkan ilmu yang ia miliki, kepekaan terhadap situasi dan isu-isu yang berkembang di tengah-tengah masyarakat, menyampaikan dakwah dengan hikmah, berakhlak mulia, berbaik sangka kepada sesama muslim, menutupi aib manusia, bergaul dengan baik, memahami kedudukan manusia dan menempatkan mereka sesuai dengan kedudukannya, saling tolong menolong sesama juru dakwah lain dalam dakwah mereka dan saling menasehati. ${ }^{8}$

Dalam berdakwah penguasaan akan ilmu agama tidaklah cukup tanpa diiringi oleh pengamalan yang istiqomah. Kemampuan beretorika tanpa diiringi oleh pengamalan terhadap ilmu dan apa yang disampaikan akan memunculkan da'i yang hanya menyampaikan ajaran agama namun miskin dari ruh, nilai dan hikmah.

Kemampuan yang mumpuni dan keselarasan antara kondisi lahir dan kondisi batin serta motivasi yang tulus ikhlas akan memunculkan da’i yang ideal. Diantara syarat-syarat seorang da'i ideal adalah memiliki akidah yang kuat, ibadah yang rajin, berakhlak yang mulia, mempunyai kemampuan ilmiah yang luas, memiliki kondisi fisik yang sehat dan baik, fasih berbicara dan berdedikasi yang tinggi. ${ }^{\text {? }}$

Seorang da'i sendiri sebelum melakukan dakwah hendaknya melakukan persiapan-persiapan baik persiapan pengetahuan maupun persiapan keimanan dan ketaqwaan, karena dakwah bukan sekedar menyampaikan dan mengajak tanpa mengamalkan.

Terdapat dua persiapan utama yang harus dilakukan oleh seorang da'i sebelum melaksanakan dakwah yaitu persiapan mental (al-i'dad al-fiqri) dan persiapan ilmu (al-i'dad al-ilmiyah). Dalam melaksanakan tugasnya seorang mubaligh harus mampu memelihara ketenangan dan keseimbangan jiwa, dan sanggup pula memulihkan keseimbangan itu bila terganggu oleh reaksi dan aksi dari mad'u. Jangan bersedih bila ditolak, didustakan, dicemooh dan disakiti. Selain itu persiapan ilmiah juga tidak kalah penting, mubaligh harus mengetahui fitrah manusia, sifat-sifat dan tingkah laku, cara berfikir dan perasaan objek dakwah yang dihadapinya. Selain hal tersebut

${ }^{8}$ Muhammad Abu Fath al Bayanuni, Madkhal Ila Ilmi Dakwah (Madinah:

Muasasah Risalah, 2005), 155-167.

${ }^{9}$ Masyhur Amin, Dakwah Islam dan Pesan Moral (Yogyakarta: Al Amin, 1997), 70. 
da'i juga harus mengetahui ajaran-ajaran agama serta mazhab-mazhabnya, sistem kemasyarakatan dan falsafah yang terdapat dalam masyarakat tersebut. ${ }^{10}$ Pengetahuan akan ilmu agama merupakan hal mendasar dalam kegiatan dakwah, da'i harus memahami bahwa mereka mengajak kepada Allah SWT.

Menurut Aziz al-Anzi wajib bagi seorang da'i untuk mengetahui ilmu syariah, yaitu apa yang diturunkan Allah SWT kepada Rasulnya Muhammad SAW baik al-Qur'an, hikmah, mengetahui apa yang Allah maksudkan dan inginkan, dan memahaminya sebagaimana pemahaman para sahabat dan tabi'in dan para imam. Karena kesuksesan dakwah adalah bergantung kepada ilmu yang diwariskan oleh Rasulullah SAW. ${ }^{11}$

Da'i hendaklah mengikuti dan meneladani sifat-sifat yang dimiliki oleh nabi Muhammad SAW, dan diantara sifat-sifat utama yang mesti dimiliki oleh sorang da’i yaitu; da’i hendaknya memiliki keinginan yang kuat agar manusia mendapatkan hidayah, zuhud terhadap dunia dan kesenangankesenangannya yang sia-sia dan menyalahi agama, bersifat mulia, kasih sayang kepada makhluk Allah swt, memahami ilmu fiqih, jujur, memahami sifat dan psikologi objek dakwah atau mad'u, mengakui nikmat-nikmat Allah swt keatas manusia dan senantiasa membicarakannya dengan maksud syukur dan memuji Allah swt, memiliki iman yang kuat, mencintai Allah swt dan Rasulnya, berkeinginan kuat dan tamak untuk menggapai husnul khatimah, bersabar terhadap kesulitan dan kesukaran dalam dakwah, menolong para pendosa kepada ketaatan, senantiasa berada dalam kebaikan, berkata dengan lemah lembut, berakhlak mulia, cerdas dan rajin, bersegera kepada kebaikan, mengharapkan pahala dan ganjaran dari Allah swt, semangat untuk memperbaiki dan mendamaikan manusia. ${ }^{12}$

Para juru dakwah bekerja untuk menyeru dan mengajak manusia untuk beriman dan mentaati perintah Allah SWT baik dalam wilayah aqidah, syari'ah dan akhlakul karimah dan dalam kegiatannya seorang juru dakwah diharapkan memiliki kompetensi sehingga dapat diterima oleh mad'u dimana selanjutnya kompetensi keagamaan personal dan

\footnotetext{
${ }^{10}$ Natsir, Op. Cit., 133

${ }^{11}$ Al-Anzi, Aziz. Basbirah fi Da'wah ila Allah (Abu Dhabi: Dar Imam Malik. 2005),
} 30.

12 Said al-Qahtani. Fiqh Da'wah fi Shahih Imam Bukhari. (Saudi: Wizarah Su'unul Islamiyah wa Awqaf. 2000), 1087-1094 
kemampuan berkomunikasi baik verbal maupun non verbal menjadi pilar utama dalam berdakwah. Penelitian ini mencoba menggali lebih jauh kompetensi yang seharusnya dimiliki oleh juru dakwah menurut pandangan Jama'ah Tabligh.

Untuk memperoleh data mengenai pandangan jama'ah tabligh mengenai kompetensi yang seharusnya dimiliki oleh seorang juru dakwah dibutuhkan dilakukan studi kepustakaan pada buku-buku yang menjadi rujukan dalam dakwah JT juga informasi tambahan diperoleh melalui observasi parsitipasi yang dilakukan dengan turut serta dalam kegiatan khuruj selama 3 hari, 40 hari dan mengunjungi pusat gerakan Jama'ah Tabligh di masjid Banglawali Nizamuddin India dan Masjid Kakrael Bangladesh serta beberapa pusat kegiatan Dakwah jama'ah Tabligh di beberapa daerah di Indonesia. Hasil penelitian juga diperkaya dengan mewawancarai informan dari para da'i Jama'ah Tabligh di pusat Jama'ah Tabligh Kabupaten Rejang Lebong yang berlokasi pada Mushollah alHijrah di Pondok Pesantren al-Fatah Tabarenah Curup.

\section{Hasil dan Pembahasan}

Dakwah merupakan aktivitas sosial dimana nilai-nilai kegamaan di sosialisasikan dan dalam selanjutnya dibumikan dalam kehidupan baik secara personal maupun dalam masyarakat. Aktivitas dakwah tersebut bertujuan pada perubahan akhlak, pemahaman akan agama yang lurus dan prilaku masyarakat sesuai dengan nilai-nilai yang terkandung dalam alQur'an dan Hadits dan untuk selanjutnya mewujudkan kehidupan sosial masyarakat yang Islami.

Gerakan dakwah Jama'ah Tablih terus mengalami perkembangan dari tahun ketahun, melitasi negara, gerakan dakwah non politik JT membuat dakwah lebih mudah diterima di banyak negara. Dibanyak negara-negara markas-markas dakwah Jama'ah tabligh terus bermunculan dan dalam pertemuan tahunan dunia Jama'ah Tabligh di daerah Tonggi Bangladesh dihadiri oleh Jutaan pendakwah JT dari beragam negara termasuk Indonesia menjadi bukti diterimanya dakwah JT diberbagai negara.

Dalam pandangan JT pemahaman akan agama dan hakekat dakwah tidak dapat diperoleh bila hanya bertumpu pada literatur 
keagamaan, mempraktekkan apa yang diketahui dengan melakukan program khuruj merupakan salah satu metode utama dalam merubah tingkah laku individu dan untuk menyiapkan seorang da’i. dalam praktek kburuj diharapkan akan terbentuk sifat pada individu dimana sifat tersebut merupakan hasil yang muncul karna pengorbanan yang dilakukan dengan berkelanjutan untuk agama.

Kegiatan dakwah yang dilakukan menurut JT bukanlah sebatas berceramah ataupun menyampaikan perkara-perkara agama, namun lebih dari itu aktivitas dan kegiatan dakwah bertujuan untuk memperbaiki diri da'i dan mewujudkan agama dalam dirinya secara bertahap-tahap. Para da'i JT dalam kebanyakan bayan ${ }^{13}$ mereka selalu menjelaskan bahwa mereka mengajak kepada Allah swt bukan kepada golongan, partai atau ormas. Da'i JT menjadikan Qur'an surat Yusuf Ayat 108 sebagai dalil bahwa da'i adalah mereka yang mengajak kepada Allah SWT dengan mengikuti jalan nabi Muhammad SAW.

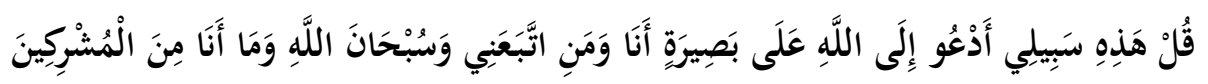

Katakanlab: "Inilah jalan (agama) ku, aku dan orang-orang yang mengikutiku mengajak (kamu) kepada Allah dengan hujah yang nyata, Maha Suci Allah, dan aku tiada termasuk orang-orang yang musyrik".

Gerakan JT juga terbukti mampu membentuk da'i-da'i yang siap diterjunkan ke berbagai wilayah baik dalam ataupun luar negeri, yang siap berkorban harta, diri dan waktu untuk agama. Sebagai upaya memperbaiki diri dan menyiapkan da'i yang berkompeten, salah satu metode yang digunakan adalah dengan meluangkan dan menyediakan waktu untuk beri'tikaf dari masjid ke masjid atau yang dikenal dengan istilah kburuj. Aktivitas khuruj tiga hari untuk pemula dimana individu dilatih untuk memberbaiki diri dengan duduk dalam ta'lim, mendengarkan ceramah, bermudzakarah, menghidupkan malam dengan sholat dan ibadah serta berlatih berdakwah.

Dakwah dalam khuruj yaitu dengan mengajak orang lain untuk memakmurkan masjid, mengajak melaksanakan sholat lima waktu

${ }^{13}$ Bayan merupakan istilah lain yang digunakan oleh kalangan JT untuk ceramah atau tausyiah, berasal dari bahasa Arab بين yang bermakna terang dan jelas. 
berjama'ah dan dengan menyampaikan keutamaan dan ganjaran yang akan diperoleh baik di dunia maupun di akhirat bila melakukan amalan-amalan agama. Kegiatan dakwah tersebut biasa dilaksanakan dengan cara berkeliling dari satu rumah kerumah yang lain yang dikalangan JT dikenal dengan istilah jaulah.

Jama'ah Tabligh memandang bahwa untuk memulai berdakwah ataupun mengajak orang lain kepada kebikan tidak disyaratkan memiliki kemampuan keagamaan diatas rata-rata. JT berpedoman pada pemahaman akan hadits Nabi saw yang memerintahkan untuk menyampaikan apa yang dari Nabi saw meskipun hanya satu ayat. Maka apa yang baru diketahui bila telah diamalkan boleh disampaikan.

Aktivitas khuruj diharapkan mendatangkan beberapa sifat yang diharapkan dimiliki oleh seorang da'i, dan khuruj merupakan sarana untuk memperbaiki individu secara bertahap-tahap dan berkelanjutan yang nantinya akan membentuk insan yang memiliki kompetensi keimanan dan kemampuan untuk berdakwah. Dalam pandangan JT seorang da'i tidaklah sama dengan ustadz, kiai atau guru agama, untuk menjadi ustadz atau guru agama diwajibkan memiliki pengetahuan mengenai ilmu-ilmu agama secara mendalam, sebaliknya menjadi da'i tidaklah diisyaratkan menguasai seluk beluk ilmu agama secara mendalam, aktivitas mengajak untuk menjadi baik berbeda dengan mengajar agama, mengajak warga untuk hadir mengikuti pengajian yang dibimbing oleh seorang ustadz atau maulana ${ }^{14}$ dapat dilakukan oleh siapa saja.

Aktifitas kburuj dalam pandangan JT merupakan sarana yang bertujuan untuk membentuk da'i yang memiliki kompetensi kepribadian dimana seorang juru dakwah memiliki kompetensi atau sifat personal diantaranya sifat taat, sabar, taqwa, tawajjuh. ${ }^{15}$ Dengan melakukan kegiatan dan program khuruj serta mengorbankan waktu, diri dan harta untuk keperluan agama akan diharapkan mendatangkan sifat-sifat tersebut,

${ }^{14}$ Maulana atau moulvi merupakan gelar kehormatan yang diberikan untuk mereka yang telah menyelesaikan pendidikan agama di madrasah atau pesantren di India, Pakistan, Bangladesh dan Afrika Selatan. Dengan memiliki kompetensi penguasaan akan hadits, atau hafal Al-Qur'an dan menguasai Bahasa Urdu. Khusus untuk Afrika Selatan gelar maulana hanya digunakan pada madrasah yang berafiliasi dengan gerakan Jama'ah Tabligh

${ }^{15}$ Abu Fathimah. Jaulah Dakwah Cara Ambiya' (Jakarta: Annisa, 2008), 44-45. 
kegiatan khuruj sendiri dimaksudkan sebagai sarana dalam untuk memperbaiki umat secara bertahap-tahap.

Ketaatan, atau sifat taat merupakan bentuk ketundukan dan kepatuhan atas perintah Allah swt, perintah Nabi saw maupun keputusan hasil musyawarah agama baik perintah tersebut disukai ataupun tidak. Aktivitas khuruj JT dipimpin oleh seorang amir yang dipilih berdasarkan musyawarah, ketaatan kepada amir menjadi kewajiban bagi setiap anggota rombongan, Amir jama'ah yang memutuskan petugas-petugas dan mengatur arah dakwah selama khuruj.

Sifat selanjutnya taitu Sabar, merupakan sifat tabah atas kesulitan yang dihadapi dalam berdakwah, bersabar atas penolakan-penolakan ataupun pengusiran dari mad'u, tidak berkeluh kesah dan meyakini bahwa sumber kesulitan yang dihadapi dalam berdakwah bukan berasal dari mad'u tetapi disebabkan karena kurangnya kesungguhan dalam berdakwah. Da'i juga harus sabar dalam mentaati perintah amir sebagai pimpinan rombongan, dan mematuhi keputusan musyawarah. Da'i JT bergerak berdasarkan musyawarah bukan berdasarkan keinginan diri sendiri, menurut JT bergerak atas keinginan diri sendiri akan menimbulkan perpecahan dalam rombongan, karena diri rawan dipengaruhi nafsu dan setan.

Taqwa, merupakan hal yang seharusnya dimiliki oleh setiap juru dakwah, ketaqwaan dalam setiap keadaan dan kondisi. Dalam pandangan JT ketaqwaan kepada Allah swt hendaknya tidak berubah meskipun seorang juru dakwah mendapatkan penentangan dalam dakwahnya.

Tawajjuh, merupakan sifat kesungguhan dalam menerima nasihat dan ajaran agama dan kesungguhan dalam memperbaiki diri dan berdakwah. Seorang da'i hendaknya memberikan perhatian sepenuhnya dan menganggap dakwah sebagai pekerjaan utama dan menjadikan profesi dalam mencari nafkah kebutuhan hidup sebagai pekerjaan sampingan, tawajjuh menjadikan dakwah sebagai maksud dan tujuan hidup dan menjadikan sebagai pandangan hidup.

Dalam berdakwah da'i harus menghilangkan niat dan anggapan bahwa tujuan berdakwah adalah untuk memperbaiki orang lain tetapi meniatkan bahwa dakwah adalah untuk memperbaiki diri sendiri, berdakwah bukan hanya menyampaikan ilmu tetapi lebih menitik beratkan 
pada penerapan ilmu sehingga mad'u bukan hanya mendapatkan transfer pengetahuan agama tetapi lebih dari itu mad'u diharapkan menerapkan apa yang diketahui dengan langsung mengamalkan dalam dikemas dalam kegiatan khuruj yang meliputi i'tikaf, membaca al-Qur'an, berdzikir, mendengarkan taklim, dan bermudzakarah.

Menurut JT seorang da'i dalam berdakwah hendaknya menyertakan tiga hal: pertama, meniatkan bahwa dalam berdakwah bukan untuk memperbaiki orang lain tetapi untuk memperbaiki diri sendiri. Kedua, meniatkan bahwa berdakwah dalam rangka membantu masyarakat dalam menghidupkan kegiatan peribadatan di masjid ataupun di kampung tersebut. Ketiga, mengajak jama'ah masjid dimana dakwah dilaksanakan untuk turut serta berpartisipasi menghidupkan amalan masjid.

Amalan masjid yang harus diusahakan dan dihidupkan dalam merupakan amalah masjid Nabawi di Madinah yang dulu dihidupkan dan dilaksanakan pada masa Rasulullah saw. Amalan masjid tersebut terdiri dari empat hal yaitu taklim wa ta'alum, dakwah ilaallah, dzikir ibadah dan kbidmat.

Ta'lim dan ta'alum yang merupakan kegiatan mengedukasi umat serta memberikan motivasi untuk beramal dengan cara menyampaikan keutamaan, fadilah, ganjaran dan balasan bagi mereka yang beramal baik. Dalam pandangan JT seorang da'i hendaknya menyampaikan kabar gembira bukan menakuti mad'u, menyampaikan pahala dan ganjaran bukan azab dan hukuman. Dalam kegiatan ta'lim wa ta'alum biasanya dilakukan dengan cara membaca buku Fadhilah Amal, Fadhilah Sedekah, Muntakhab Ahadits dan Hayatus Sahabah. Ta'lim wa ta'alum bertujuan membangkitkan semangat beribadah dan memberikan pemahaman tentang pengetahuan agama dan ibadah.

Džikir ibadah, masjid menjadi hidup dengan adanya ibadah, dan aktivitas dzikir merupakan salah satu bentuk ibadah yang bukan hanya menghidupkan masjid tetapi juga menghidupkan hati. Amaliah dzikir dalam pandangan JT haruslah dirutinkan setiap pagi dan petang. Dan amaliah dzikir yang dianjurkan dalam JT untuk dirutinkan setiap pagi dan petang adalah mengucapkan subhanallah wal hamdulillah wala ilaha illallah Allabu akbar 100 kali, shalawat 100 kali dan istighfar 100 kali.

Dakwah ilallah dan khidmat, dakwah ilallah dan khidmat merupakan dua aktivitas yang dalam pandangan JT tidak dapat dipisahkan. Aktivitas 
13

dakwah dimasjid hendaklah diiringi dengan khidmat atau pelayanan terhadap jamaah. Dakwah ilallah dilaksanakan dengan membentuk grup yang terdiri dari beberapa orang yang mendatangi rumah masyarakat mengajak warga disekitar masjid untuk memakmurkan masjid, kegiatan dakwah yang rutin dilaksanakan juga dipadukan dengan pengajian dan pelayanan yang disingkat dengan DTI (dakwah, taklim dan istiqbal). Dalam kegiatan DTI jamaah yang hadir dipecah menjadi dua grup. Grup pertama didalam masjid dimana dipilih satu orang untuk menyampaikan tausiyah dan satu orang untuk menyambut warga yang mendatangi masjid. Grup kedua mendatangi warga sekitar. DTI menuntut da'i untuk mampu menyampaikan pesan-pesan agama dengan bahasa yang mudah dipahami, tidak berkesan mengajari, santun, bersikap ramah dan murah senyum.

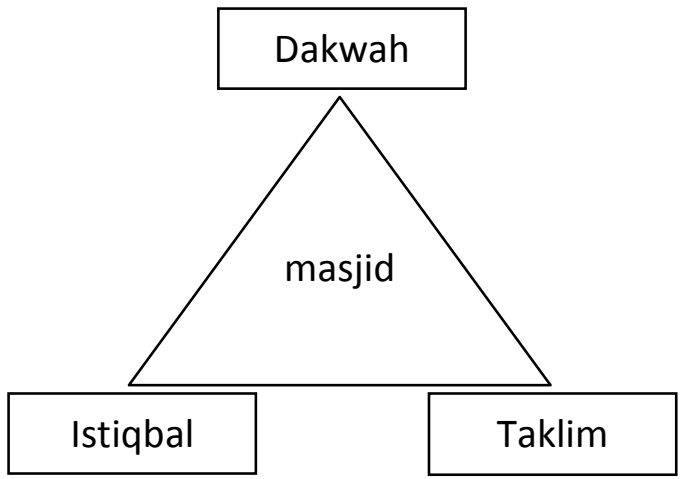

bagan 1: segitiga kegiatan dakwah (DTI) Jamaah Tabligh

Dikalangan Jama'ah Tabligh terdapat beberapa kompetensi yang harus dimiliki oleh seorang da'i yang dalam pandangan jamaah tabligh dikenal dengan istilah "sifat". Sifat-sifat yang mesti dimiliki oleh da'i tersebut terdiri dari 13 sifat. Meskipun demikian menurut JT seseorang tidaklah dituntut untuk menguasai banyak ilmu agama untuk menjadi da’i, meskipun baru mengetahui satu ilmu seseorang boleh menyampaikannya kepada orang lain. Hal tersebut didasarkan pada hadits Nabi SAW

Sifat pertama, mababbah kepada semua mabluk. Mahabbah bermakna rasa cinta kasih, dalam pandangan JT rasa kasih sayang tidaklah terbatas kepada manusia saja tetapi harus menyeluruh kepada seluruh makhluk meliputi, manusia, hewan, tumbuhan ataupun benda-benda mati. Seorang 
da'i dalam menunjukkan rasa kasih sayang kepada manusia tanpa membedakan kepercayaan yang dianut, karena da'i dalam menyeru manusia kepada Allah swt sesungguhnya menyelamatkan manusia tersebut dari siksa neraka. Manusia memiliki perbedaan kepercayaan dan keyakinan, mencintai manusia adalah dengan mengajak mereka kepada Allah swt dengan cara yang santun dan menghargai kedudukan mereka sebagai makhluk ciptaan Tuhan. Seorang da'i akan bersedih hati bila melihat manusia meninggal dalam keadaan tidak beriman kepada Allah swt ataupun dalam kemaksiatan, da'i yang baik melihat mereka yang belum beriman atau yang bermaksiat sebagai ladang yang harus diperhatikan dan diprioritaskan bukan dijauhi dan dimusuhi.

Rasa cinta da'i kepada seluruh makhluk berangkat dari pemahaman bahwa seluruh makhluk merupakan hamba Allah swt dan apa-apa saja yang diciptakan oleh Allah swt selain manusia adalah diciptakan untuk berkhidmat kepada Allah swt. Dan rasa cinta tersebut merupakan rasa cinta yang muncul karna cinta kepada Allah swt dan karna Allah swt.

Sifat kedua, Rela berkorban untuk agama baik barta, diri dan waktu. Seorang da'i Jama'ah Tabligh diuji kesediaan untuk berkorban lewat kegiatan khuruj. Dalam kegiatan tersebut peserta diharuskan menyiapkan biaya untuk digunakan selama kegiatan dan juga menyiapkan keperluan keluarga yang ditinggalkan selama khuruj. Da'i juga menyiapkan waktunya selama tertib masa yang diprogramkan bervariasi mulai dari 3 hari, 40 hari, 4 bulan, satu tahun bahkan seumur hidup.

Sifat ketiga, seorang da'i memiliki niat ishlah diri atau memperbaiki diri. Dalam pandangan JT menjadi kewajiban da'i untuk menjadikan niat memperbaiki diri sebagai salah satu tujuan utama. Seorang da' ketika melaksanakan aktifitas khuruj bukanlah bermaksud untuk mengajari orang lain apalagi memperbaiki orang lain. Dalam menyampaikan pesan-pesan dakwah baik dalam komunikasi antar personal ataupun dalam ceramah, apa yang disampaikan sesungguhnya disampaikan kepada diri sendiri, apabila pesan-pesan tersebut didengar dan diterima oleh mad'u maka itu merupakan anugrah dari Allah swt namun memperbaiki diri tetap menjadi tujuan utama.

Sifat keempat, Mencari ridho Allah SWT. Sifat yang ini juga merupakan tujuan utama dalam berdakwah. Tujuan dakwah untuk mencari harta benda dunia akan mengakibatkan da'i tergelincir dan melakukan perbuatan dosa. Seorang da'i harus meluruskan niatnya dan menjadikan Allah sebagai tujuan dalam setiap amalan, dan diantara maksud dari dakwah Jama'ah Tabligh adalah untuk merubah keyakinan dari makhluk kepada khalik. 
Sifat kelima, da'i ideal adalah selalu beristighfar setelab beramal, beristighfar sebagai bentuk kekhawatiran seorang da'i atas niat yang belum betul dan tidak ikhlas dalam berdakwah serta rasa khawatir apabila amal tidak diterimanya oleh Allah SWT. Memohon ampun kepada Allah banyak dicontohkan oleh nabi muhammad saw, sebagaimana yang diceritakan dalam hadits:

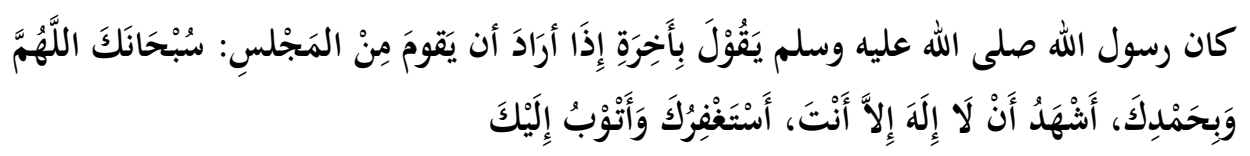

Bahwa Rasulullah saw bila hendak berdiri dari majelis mengucapkan: "maha suci engkau (Allab) segala pujian untuknya, aku bersaksi tidak ada tuban selain engkau dan aku memohon ampunan dan bertaubat kepadamu". (H.R. Abu Daud) ${ }^{16}$

Sifat selanjutnya yang merupakan sifat ke enam yakni Tabah menghadapi semua ujian. Ujian yang dihadapi dalam berdakwah merupakan suatu keniscayaan, ujian juga dahulu dihadapi oleh para nabi dan rasul. Ujian yang dihadapi oleh da'i selain berasal dari luar dapat pula dari dalam. Dari luar berasal masyarakat baik berupa penolakan ataupun penerimaan, dalam menghadapi penolakan da'i harus bersabar dan jangan sampai keluar kata-kata kasar serta do'a-do'a buruk atas mad'u dan menggantinya dengan do'a memohon hidayah kepada Allah swt baik dalam sholat ataupun diluar sholat. Sedangkan dalam menghadapi penerimaan da'i harus bersyukur dan meyakini bahwa semua penerimaan adalah berkat pertolongan dari Allah SWT, bukan karna kerasnya usaha dan bagusnya ceramah. Ujian dari dalam dapat berasal dari keluarga berupa penolakan dan dapat pula berasal dari diri da'i pribadi berupa rasa kurang sabar dalam menghadapi ujian dalam dakwah ataupun rasa bangga dan kagum terhadap diri sendiri saat dakwah ya ia lakukan diterima oleh mad'u.

Sifat ketujuh yaitu, Menisbatkan diri banya kepada Allah SWT. Da'i Jama'ah Tabligh hendaknya meyakini bahwa seluruh pertolongan berasal dari sisi Allah SWT bukan dari dirinya. Meyakini bahwa tidak ada dapat menolong kecuali Allah SWT dan hidayah merupakan karunia dari Allah SW'T ke atas hambanya. Seorang da'i hanyalah memohon supaya Allah SWT menganugrahkan hidayah yang terdapat pada khazanah Allas SWT kepada mereka yang belum menerima hidayah.

Sifat kedelapan, Tidak putus asa terhadap segala kegagalan. Kegagalan bagi juru dakwah adalah hal biasa, seorang da'i harus berpandangan bahwa bukanlah hasil dakwah saja yang dilihat oleh Allah SWT tetapi usaha da'i

${ }^{16}$ Abu Daud. Sunan Abu Dand juz 04 ( Beirut: Maktabah Ashriyah, 1999), 264 
yang bersungguh-sungguh dan tanpa pamrih serta do'a-do'a dimalam hari pada saat sholat tahajud serta segala upaya dalam mengajak mad'u kepada Allah SWT untuk mentaati perintahnya dan menjauhkan larangannyalah yang juga akan dilihat oleh Allah SWT. Da'i hendaknya memahami bahwa berputus asa merupakan hal yang tercela dan Allah swt tidak menyukai orang yang berputus asa, da'i belajar dari kegagalan untuk mencapai kesuksesan dan mencari solusi-solusi bersumberkan Al-Qur'an dan Hadits.

Sifat kesembilan, sabar seperti onta. Onta merupakan salah satu hewan yang diceritakan didalam al-Qur'an. Allah swt meminta manusia untuk memperhatikan bagaimana penciptaan unta. Sebagai hewan padang pasir unta memiliki banyak kelebihan. Unta dapat hidup pada suhu yang dapat mengakibatkan kematian pada kabanyakan makhluk hidup, unta juga mampu bertahan tidak makan dan minum selama beberapa hari. Atas dasar inilah para da'i jamaah tabligh menjadikan sifat sabar onta dalam memikul beban dan menahan kesulitan sebagai perumpamaan.

Sifat kesepuluh, tawadhu' seperti bumi, tawadhu' merupakan sikap dimana seseorang menampakkan diri lebih rendah pada orang yang ingin mengagungkannya atau bermakna memuliakan orang yang lebih mulia darinya. ${ }^{17}$ Tawadhu' merupakan salah satu sifat Rasulullah SAW yang dengannya beliau mendapatkan keutamaan. Ketika Nabi Muhammad SAW di tawarkan untuk memilih antara menjadi Nabi dan raja atau menjadi Nabi dan hamba beliau memilih menjadi Nabi dan hamba. ${ }^{18}$ Seorang da'i hendaklah meniru bumi yang walaupun diinjak tetap memberikan manfaat, dan bumi memberikan banyak manfaat kepada manusia dan hewan tetapi tetap rendah dan selalu berada dibawah.

Sifat kesebelas, tegak seperti gunung. Da'i mengambil pelajaran dari kesungguhan gunung, berdiri tegak tidak goyang diterpa badai angin dan hujan, tidak luluh menghadapi panas matahari. Gunung kokoh terpancang demikian juga da'i kokoh memegang prinsip-prinsip agama tidak goyang dengan cercaan dan ejekan, tidak lemah dengan penolakan dan hambatan, tidak terpengaruh oleh suasana dan keadaan. Dengan kata lain seorang da'i harus istiqomah dalam memperjuangkan apa yang ia yakini karena dakwah merupakan panggilan keimanan.

Sifat kedua belas, berpandangan luas seperti langit. Seorang da'i menurut JT janganlah melihat kepada sesuatu dengan pandangan sempit, pahami bahwa diatas langit ada langit dan da'i hendaknya berpandangan luas melihat bahwa kehidupan yang perlu dilihat adalah kehidupan sesudah mati, kehidupan hari ini adalah sarana untuk menggapai kebahagiaan nanti di

\footnotetext{
${ }^{17}$ Al-Asqalani. Fathul Bari 1 (Kairo: Al Maktabah AS Salafiyah, 1960), 341

${ }^{18}$ Kamsahuni. Jami'u Ushul fi Auliya' (Surabaya: Al Haramain, Tanpa Tahun), 56
} 
akhirat. Juru dakwah hendaknya meyakini bahwa ada hal-hal yang tidak diketahui dibalik yang terlihat yang merupakan hikmah dari kebijaksanaan Allah SWT. Memandang luas seperti langit dimaksudkan sebagaimana langit yang menanungi bumi, langit dapat menyaksikan apa-apa yang terjadi dibumi secara menyeluruh maka seorang da'i janganlah memandang sesuatu secara parsial, jangan memvonis dan menghakimi.

Sifat ketiga belas, bergerak memberi manfaat seperti matahari. Da'i hendaknya jangan menunggu datangnya mad'u, tetapi haruslah aktif mendatangai objek dakwah tidak menunggu diundang. Seorang juru dakwah hendaklah meniru bagaimana nabi Muhammad SAW berkeliling mendatangi umat menyampaikan Islam dari rumah ke rumah. Juru dakwah meniru bagaimana matahari bergerak menyinari bumi tanpa meminta imbalan. Demikian pula da'i menyampaikan pencerahan kepada umat tanpa mengharap balasan melainkan ganjaran dari Allah SWT nanti di akhirat. Dalam dakwah Jama'ah Tabligh implementasi dari bergerak memberi manfaat seperti matahari terlihat dalam aktifitas jaulah ketika tengah melakukan khuruj baik 3 hari, 40 hari ataupun 4 bulan, dan mendatangi umat dua setengah jam setiap hari ketika sedang menghidupkan maqomi. ${ }^{19}$

Selain kompetensi tersebut dalam mengajak manusia kepada Allah SWT seorang da'i harus mendatangi umat bukan didatangi, mendatangi tanpa menunggu undangan dan jemputan. Da'i dalam berdakwah hendaknya memberikan contoh bukan sekedar ucapan, menghidupkan sunnah-sunnah Rasulullah SAW bukan sekedar manidzah hasanab tetapi juga sebagai uswatun hasanah, membicarakan keagungan alam akhirat bukan kehebatan makhluk. Seorang da'i juga tidak mengharapkan upah dari dakwahnya tetapi mengorbankan harta benda dan dirinya untuk dakwah. ${ }^{20}$

Seorang da'i dalam pandangan JT harus memiliki keyakinan kepada Allah SWT diatas keyakinan kepada makhluk, upaya mengeluarkan keyakinan kepada selain Allah dari dalam hati merupakan upaya yang harus terus-menerus dilakukan seeorang juru dakwah sehingga ia berhasil memasukan keyakinan kepada Allah SWT saja kedalam hati. Seorang da'i hendaknya menjadikan dakwah sebagai maksud hidup, dan memahami bahwa maksud dari ia diciptakan oleh Allah swt adalah untuk beribadah kepadanya, sebagai wakil Allah SWT yang bertanggung jawab untuk memakmurkan bumi. Maksud memakmurkan bumi bukan hanya dengan

19 Maqomi merupakan tempat dimana seorang da'i tinggal, apabila tidak sedang menjalani khuruj maka da'i memakmurkan masjid dimana ia tinggal. Maqomi berasal dari bahasa Arab secara bahasa bermakna tempat dimana kedua kaki berada.

${ }^{20}$ Ishaq Shahab. Kburuj fi Sabilillah Sarana Tarbiyah Umat Untuk. Membentuke Sifat Imaniyah (Bandung: Pustaka Ramadhan, tt), 20 
hal-hal yang bersifat jasmaniyah berupa kebutuhan-kebutuhan hidup didunia tetapi memakmurkan bumi dengan ketaqwaan dan amalan-amalan yang dapat menyelamatkan kehidupan baik di dunia maupun diakhirat.

Da'i juga harus memahami bahwa tujuan ia diciptakan oleh Allah swt adalah untuk melanjutkan usaha kenabian, setelah Rasulullah SAW wafat tugas mengajak manusia kepada Allah SW'T dilimpahkan kepada umatnya.

Menurut Jama'ah Tabligh untuk dapat melakukan dakwah seseorang tidak harus menguasai seluruh ilmu agama, sebagaimana para sahabat yang baru memeluk Islam tidak diminta untuk memahami dulu seluruh agama baru menyampaikannnya kepada orang lain, tetapi apa yang diketahui oleh seseorang meskipun hanya sedikit boleh langsung disampaikan dan diajarkan kepada orang lain. Jama'ah Tabligh menjadikan hadits nabi mengenai perintah untuk menyampaikan yang terdapat dalam shahih Bukhari sebagai dalil.

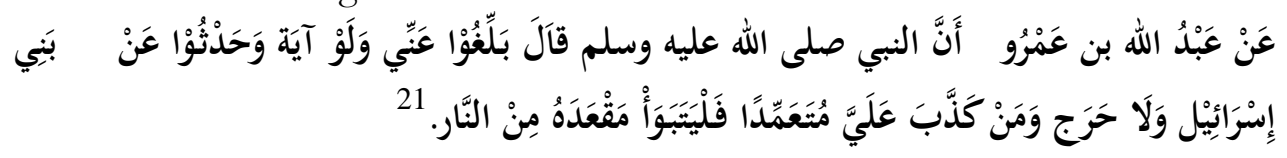

Dari Abdullab bin Amru bahwa Nabi SAW bersabda: "Sampaikanlah olebmu dariku walau satu ayat dan barang siapa yang berdusta atas namaku dengan sengaja maka disiapkan baginya tempat duduk dari api neraka" (H.R. Bukhari)

Hadits tersebut memerintahkan untuk menyampaikan walaupun satu ayat pendek dari al-Qur'an, dan menyampaikan al-Qur'an berarti menyampaikan apa yang disampaikan oleh Rasulullah SAW, dan dipahami juga menyampaikan hadits dari Rasulullah. sebagian ulama menjelaskan bahwa maksud hadits tersebut yang disampaikan baik al-Qur'an, hadits ataupun perkataan-perkataan yang baik yang bersumber dari al-Qur'an dan Hadits.

Menjadi persoalan selanjutnya apakah seorang yang mengetahui satu ayat boleh menyampaikan didalam majelis yang didengarkan banyak orang, ataupun menyampaikan apa yang diketahui diatas mimbar. Keadaan tersebut seakan mempertanyakan kualitas dan kompetensi yang harus dimiliki oleh seseorang sebelum berdakwah. Dalam aktifitas khuruj, JT memiliki standar kafilah dakwah yang elegan, dalam satu kafilah selalu diupayakan terdiri dari uztadz yang memahami fiqh, hafiz al-Qur'an, orang tua atau orang yang telah lama berdakwah. Sehingga dalam kegiatan khuruj orang-orang yang baru ikut pertama kali yang belum memiliki kemampuan dan ilmu agama tidak diminta untuk untuk memberikan bayan, mudzakarah

${ }^{21}$ Al-Bukhari. Shabih Bukhari (Beirut: Darul Kutub Islamiyah, 2015), 636 
atau berkhutbah Kegiatan khuruj orang-orang baru lebih difokuskan pada usaha memperbaiki diri secara bertahap-tahap sembari belajar menyampaikan apa yang diketahui meskipun hanya satu ayat, JT berpendapat seorang da'i tidak harus menunggu baik dulu secara keseluruhan baru berdakwah, karena manusia tidak ada yang sempurna dan memiliki kekurangan dan pernah melakukan kesalahan.

\section{Penutup}

Gerakan dakwah Jamaah Tabligh saat ini makin dikenal dimasyarakat, meskipun dengan nama yang beragam. Dalam perkembangannya gerakan dakwah Jama'ah Tabligh telah melebarkan wilayahnya ke ranah pendidikan pesantren dalam upaya menyiapkan da'i yang memiliki kompetensi dan kualitas yang mumpuni. Hal tersebut dibuktikan dengan munculnya pesantren-pesantren di beberapa pusat dakwah Jama'ah Tabligh atau yang dikenal dengan istilah markas dakwah.

Meskipun belum seluruh da'i Jama'ah Tabligh memahami mengenai kompetensi yang harus dimiliki oleh seorang pendakwah namun Jama'ah Tabligh sendiri telah menekankan perlunya tiga belas sifat yang harus dimiliki oleh da’i dan empat sifat; taat, sabar, taqwa, tawajjuh yang diusahakan untuk terbentuk dalam diri seorang pendakwah. Adanya beberapa kabar mengenai penolakan terhadap beberapa rombongan Jama'ah Tabligh di beberapa masjid menjadi hal yang tidak dapat dihindarkan, banyak faktor yang menjadi penyebab.

Tiga belas kompetensi da'i yang menjadi garis seorang da'i Jamah Tabligh dalam dakwah seharusnya dapat lebih diperhatikan, sehingga dapat menghindarkan kesalahpahaman masyarakat yang melihat prilaku da'i JT yang terkadang belum sesuai dengan pakaian yang digunakan. Persoalan ini lebih disebabkan oleh sebagian dari Jamaah Tabligh yang baru bertaubat dan mencoba memperbaiki diri dengan turut dalam kegiatan kburuj, memakai gamis dan sorban sedangkan mereka belum meninggalkan sepenuhnya kebiasaan lama ataupun belum memahami dengan baik ajaranajaran agama, fikih dan akhlak sehingga dalam tindak tanduk sering kali menimbulkan beragam pandangan dalam masyarakat baik positif maupun negatif.

Jamaah Tabligh sendiri sesungguhnya telah menggariskan kompetensi yang harus dimiliki oleh sorang da'i, hanya saja dalam praktek lapangan da’i 
Jama'ah Tabligh tidak diharuskan sudah memiliki ketiga belas kompetensi tersebut sebelum mulai khuruj, tetapi da’i diharapkan dapat belajar menerapkan dan mewujudkan kompetensi tersebut selama khuruj. Dalam pandangan JT tujuan kegiatan khuruj yang utama bukanlah berdakwah tetapi memberbaiki diri, selama seorang da'i berniat untuk memperbaiki orang lain dengan dakwahnya selama itu ia belum mendapatkan manfaat dari apa yang ia lakukan.

\section{Daftar Pustaka}

Al-Asqalani. Fathul Bari 11. Kairo: Al Maktabah AS Salafiyah. 1960.

Al-Bukhari. Shahih Bukhari. Beirut: Darul Kutub Islamiyah. 2015.

Al-Anzi, Aziz. Bashirah fi Da'wah ila Allah. Abu Dhabi: Dar Imam Malik. 2005

al-Qahtani. Said, Fiqh Da'wah fi Shabih Imam Bukhari. Saudi: Wizarah Su'unul Islamiyah wa Awqaf. 2000.

Bayanuni, Muhammad Abu Fath al, Madkhal Ila Ilmi Dakwah. Madinah: Muasasah Risalah. 2005.

Daud, Abu. Sunan Abu Daud juz 04. Beirut: Maktabah Ashriyah. 1999.

Fathimah, Abu. Jaulah Dakwah Cara Ambiya’. Jakarta: Annisa. 2008.

Kamsahuni. Jami’u Ushulfi Auliya'. Surabaya: Al Haramain. Tanpa Tahun.

Manzur, Ibnu. Lisanul Arab vol. 14.Beirut: Dar Sadhr.

Moedjiono, Imam. Metode Dakwah Praktis. Yogyakarta: As-Salam Press. 2004.

Natsier, Muhammad. Fikhu Da'wah. Jakarta: Media Da’wah. 2006.

Risduana, Aris. "Transformasi Peran da'i dalam Menjawab Peluang dan Tantangan”. Jurnal Dakwah, Vol. XV, No.2 (2014)

Shahab, Ishaq. Khuruj fi Sabilillah Sarana Tarbiyah Umat Untuk Membentuk Sifat Imaniyah. Bandung: Pustaka Ramadhan 